\title{
Zasoby obszarów wiejskich w lokalnym rozwoju gospodarki niskowęglowej
}

\section{Rural resources in the local development of low-carbon economy}

\section{Paweł WIŚNIEWSKI}

Uniwersytet Gdański

Katedra Geografii Fizycznej i Kształtowania Środowiska

ul. Bażyńskiego 4, 80-309 Gdańsk

p.wisniewski@ug.edu.pl

\begin{abstract}
Zarys treści: Celem pracy jest ocena znaczenia zasobów obszarów wiejskich oraz możliwości wykorzystania ich potencjału w lokalnym rozwoju gospodarki niskowęglowej (niskoemisyjnej). W artykule dokonano diagnozy sytuacji obszarów wiejskich w Polsce i związanej z nimi działalności rolniczej w aspekcie gospodarki niskoemisyjnej, wskazując mocne i słabe strony oraz szanse i zagrożenia w dwóch kluczowych elementach, do jakich zaliczyć należy utrzymanie lub wzrost zdolności do pochłaniania $\mathrm{CO}_{2}$ oraz ograniczenie emisji gazów cieplarnianych z rolnictwa i gleb. Zwrócono uwagę na duży potencjał obszarów wiejskich w zakresie możliwości wykorzystania ich zasobów w celu zwiększenia sekwestracji węgla w biomasie i glebie, ograniczenia emisji gazów cieplarnianych, a także wykorzystania działalności rolniczej i przetwórstwa rolno-spożywczego wraz z biomasą drzewną do rozwoju energetyki odnawialnej, w tym do produkcji biogazu i biopaliw. Na przykładzie powiatu starogradzkiego, objętego Pilotażowym programem niskowęglowego rozwoju - pierwszym tego typu dokumentem poświęconym gospodarce niskoemisyjnej, sporządzonym w skali powiatu w Polsce - wskazano zalecane zasady funkcjonowania gospodarki niskoemisyjnej oraz kierunki niskowęglowego rozwoju na obszarach wiejskich. Podkreślono konieczność włączenia rolnictwa i terenów wiejskich do lokalnego planowania gospodarki niskoemisyjnej poprzez ich ujęcie w przygotowywanych obecnie przez jednostki samorządu terytorialnego planach gospodarki niskoemisyjnej.
\end{abstract}

Słowa kluczowe: gospodarka niskowęglowa, lokalne plany gospodarki niskoemisyjnej, obszary wiejskie, zrównoważone rolnictwo, powiat starogardzki.

\section{Wstęp}

Jak wynika z raportu Banku Światowego Transformacja w kierunku gospodarki... (2011), przejście do gospodarki o charakterze niskoemisyjnym w Polsce, chociaż nie pozbawione kosztów i trudności, jest możliwe do osiągnięcia w oparciu o kompleksowe, skoordynowane i odpowiednio wcześnie podjęte działania ze strony rządu. Skuteczna transformacja w kierunku takiej gospodarki wymaga jednak planowania i realizacji odpowiednich działań również na poziomie lokalnym. W tym celu tworzone są gminne plany gospodarki niskoemisyjnej (PGN). Stanowią one ważne dokumenty strategiczne, mające określić wizję 
rozwoju gminy w kierunku gospodarki niskowęglowej, a także zwiększyć szansę samorządów w ubieganiu się o środki unijne. Ujęte w planach zadania powinny koncentrować się na działaniach niskoemisyjnych i efektywnie wykorzystujących zasoby, służących poprawie efektywności energetycznej i wykorzystaniu odnawialnych źródeł energii we wszystkich sektorach gospodarki przy współudziale podmiotów będących producentami oraz odbiorcami energii, mieszkańców, lokalnych władz i instytucji. Tymczasem w opracowywanych obecnie PGN szczególną uwagę poświęca się zagadnieniom dotyczącym energetyki, budownictwa i transportu, marginalnie traktując rolnictwo oraz tereny wiejskie.

W szczegółowych zaleceniach dotyczących struktury planów gospodarki niskoemisyjnej, opracowanych przez Narodowy Fundusz Ochrony Środowiska i Gospodarki Wodnej, podkreślono konieczność wskazania w tych dokumentach zadań inwestycyjnych mających na celu ograniczenie zużycia energii w transporcie, budynkach lub instalacjach oraz w zakresie gospodarki odpadami i produkcji energii, a także zadań nieinwestycyjnych, takich jak: planowanie przestrzenne w miastach, zamówienia publiczne, strategia komunikacyjna, działalność promocyjna (Szczegółowe zalecenia... 2013). Pominięto obszar rolnictwa oraz terenów wiejskich, wskutek czego w przyjmowanych do realizacji przez lokalne samorządy PGN, tworzonych najczęściej na podstawie wytycznych NFOŚiGW, działania z zakresu kształtowania terenów wiejskich i środowiska rolniczego na rzecz rozwoju gospodarki niskowęglowej nie są w ogóle brane pod uwagę lub uwzględnia się je w bardzo ograniczonym zakresie. Rolnictwo nie znalazło się również wśród sektorów, które należy obligatoryjnie uwzględnić w Bazowej inwentaryzacji emisji (BEI) oraz Planach działań na rzecz zrównoważonej energii (SEAP) - kluczowych dokumentach opracowywanych przez sygnatariuszy Porozumienia Burmistrzów w sprawie Klimatu i Energii. Założenia i wytyczne tej inicjatywy Komisji Europejskiej angażującej władze lokalne i obywateli w działania na rzecz zwiększenia efektywności energetycznej i wykorzystania odnawialnych źródeł energii, skupiającej na początku 2017 r. ponad 6000 miast i gmin (w tym 40 z Polski), są także często wykorzystywane przy tworzeniu lokalnych planów gospodarki niskoemisyjnej.

Celem pracy jest zwrócenie uwagi na miejsce i rolę rolnictwa oraz terenów wiejskich w kształtowaniu gospodarki niskoemisyjnej na poziomie lokalnym w Polsce, a także wskazanie działań w tych obszarach, umożliwiających ograniczenie emisji gazów cieplarnianych i poprawę zdolności pochłaniania $\mathrm{CO}_{2}$, mogących znaleźć szerokie zastosowanie w planowaniu niskowęglowego rozwoju gmin i powiatów.

\section{Zasoby obszarów wiejskich w świetle niskowęglowego rozwoju - mocne i słabe strony oraz szanse i zagrożenia}

Aby dokonać właściwej diagnozy sytuacji rolnictwa i obszarów wiejskich w aspekcie gospodarki niskoemisyjnej, a także oceny możliwości wykorzystania ich zasobów w kierunku niskowęglowego rozwoju, wskazane jest określenie mocnych i słabych stron oraz szans i zagrożeń w dwóch kluczowych elementach: utrzymanie lub wzrost zdolności do pochłaniania $\mathrm{CO}_{2}$ oraz ograniczenie emisji gazów cieplarnianych z rolnictwa i gleb.

Do mocnych stron obszarów wiejskich pod kątem możliwości rozwoju gospodarki niskoemisyjnej w Polsce zaliczyć należy przede wszystkim duże zasoby użytków rolnych oraz możliwość wykorzystania ich potencjału w celu rozwoju upraw roślin energetycznych, a także duże zasoby leśne (tab. 1). Szczególnie wysokim udziałem gruntów ornych (powyżej 
75\% ogółu użytków rolnych) wyróżniają się województwa: kujawsko-pomorskie, łódzkie, opolskie, pomorskie, wielkopolskie i zachodniopomorskie. Województwa: podkarpackie, podlaskie i warmińsko-mazurskie charakteryzują się z kolei stosunkowo wysokim udziałem (ponad 29\%) trwałych użytków zielonych (łąk i pastwisk). Szczególnie wysoką lesistością charakteryzują się województwa: mazowieckie, warmińsko-mazurskie, wielkopolskie i zachodniopomorskie. W skali kraju w ok. 20\% gmin (głównie w województwach lubuskim, podkarpackim, pomorskim, zachodniopomorskim, warmińsko-mazurskim i podlaskim) lesistość wynosi powyżej 40\% (Polna 2005). Szczególne znaczenie mają lasy liściaste i mieszane, pochłaniające większą ilość $\mathrm{CO}_{2}$ niż drzewostany iglaste. Mocną stroną w analizowanym aspekcie jest także funkcjonowanie szkół rolniczych oraz Ośrodków Doradztwa Rolniczego. W Polsce na początku 2017 r. funkcjonowało ok. 200 szkół rolniczych, w tym 45 prowadzonych i nadzorowanych przez Ministerstwo Rolnictwa i Rozwoju Wsi. System doradztwa rolniczego tworzą Centrum Doradztwa Rolniczego w Brwinowie wraz z 3 oddziałami oraz 16 wojewódzkich Ośrodków Doradztwa Rolniczego, a także instytucje i podmioty niepubliczne. Działalność edukacyjna oraz doradcza tych jednostek powinna przyczynić się do wdrażania przez rolników odpowiednich praktyk rolniczych, sprzyjających ograniczeniu emisji z rolnictwa i gleb, obejmujących m.in. mulczowanie, orkę zachowawczą lub brak orki, utrzymywanie gleby pokrytej roślinnością lub pozostawianie na niej resztek roślinnych, a także dostosowanie zaopatrzenia w azot do zapotrzebowania roślin oraz dostosowanie systemów produkcji do maksymalnego wykorzystania odchodów zwierzęcych w uprawie roślin. Nie bez znaczenia jest także coraz częściej zauważalna i podkreślana społeczna potrzeba zachowania walorów przyrodniczych i turystycznych, zwłaszcza w powiązaniu z ochroną ekosystemów leśnych.

Do słabych stron zaliczyć należy przede wszystkim duży udział gleb ornych słabych i najsłabszych, okresowo lub stale suchych, o niskiej produktywności, ubogich w materię organiczną, co ogranicza możliwość pochłaniania $\mathrm{CO}_{2}$. W skali kraju udział takich gleb (V oraz VI klasy bonitacyjnej) wynosi 34\%. Szczególnie duży odsetek (powyżej 45\%) gleb najniższych klas bonitacyjnych występuje w województwach łódzkim, mazowieckim i podlaskim (ryc. 1). Jakość polskich gleb należy do najniższych w Europie, a potencjał produkcyjny 1 ha gleb w Polsce odpowiada potencjałowi ok. 0,6 ha gruntów ornych krajów UE (Skłodowski i Bielska 2009). Zmniejszaniu stopnia akumulacji węgla sprzyja także duży udział gleb zakwaszonych, o małej zdolności retencyjnej i niskiej zawartości próchnicy. Szczególnie wysokim udziałem (powyżej 50\%) gleb o bardzo dużym lub dużym zakwaszeniu charakteryzują się użytki rolne w województwach mazowieckim, małopolskim, łódzkim, podlaskim i podkarpackim (ryc. 2). W ostatnich kilkunastu latach w Polsce nastąpił wyraźny spadek znaczenia uprawy roślin wieloletnich - traw lub ich mieszanek z roślinami motylkowatymi (bobowatymi) - pozostawiających dużą ilość biomasy w postaci resztek roślinnych oraz poprawiających bilans azotu w glebie (Gaweł 2011; Kozłowski i in. 2011). Jak podaje A. Harasim (2015), uprawy mieszanek motylkowatych z trawami i traw stanowią zaledwie 0,6\% powierzchni kraju. Ich najniższym udziałem (wynoszącym 0,2\%) w strukturze użytkowania ziemi w 2014 r. charakteryzowały się województwa: dolnośląskie, opolskie, podkarpackie i śląskie, natomiast najwyższym (od 1,1 do 1,3\%) - podlaskie, warmińsko-mazurskie i zachodniopomorskie. Słabą stroną obszarów wiejskich w analizowanym aspekcie jest także niski poziom stabilności ekologicznej powierzchni ziemi w Polsce (Harasim 2015). Wysoką wartością tego wskaźnika, będącego ilorazem sumy powierzchni korzystnych (stabilnych ekologicznie) elementów ziemi użytkowanej rolniczo 
Tabela 1. Użytkowanie gruntów w województwach w 2015 r.

\begin{tabular}{|c|c|c|c|c|c|c|c|c|c|}
\hline \multirow[b]{3}{*}{ Województwo } & \multicolumn{6}{|c|}{ Użytki rolne } & \multicolumn{3}{|c|}{$\begin{array}{c}\text { Grunty leśne, zadrzewio- } \\
\text { ne i zakrzewione }\end{array}$} \\
\hline & \multirow[b]{2}{*}{$\begin{array}{l}\text { w tys. } \\
\text { ha }\end{array}$} & \multicolumn{5}{|c|}{ w tym (w\%) } & & \multicolumn{2}{|c|}{ w tym (w\%) } \\
\hline & & 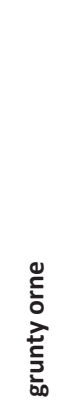 & 龸 & 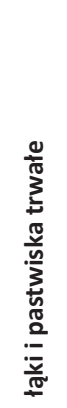 & 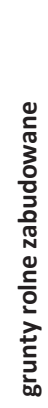 & 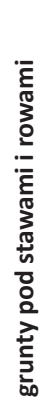 & $\begin{array}{l}\text { w tys. } \\
\text { ha }\end{array}$ & 齐 & 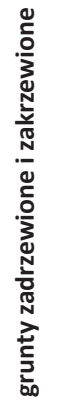 \\
\hline Dolnośląskie & 1185,3 & 73,4 & 0,5 & 21,6 & 2,5 & 2,0 & 625,8 & 97,7 & 2,3 \\
\hline Kujawsko-pomorskie & 1169,2 & 84,9 & 1,0 & 11,2 & 2,0 & 0,9 & 438,9 & 97,7 & 2,3 \\
\hline Lubelskie & 1757,4 & 74,8 & 1,9 & 18,5 & 3,6 & 1,2 & 608,6 & 95,9 & 4,1 \\
\hline Lubuskie & 565,1 & 71,2 & 0,5 & 24,1 & 2,5 & 1,7 & 718,8 & 98,9 & 1,1 \\
\hline Łódzkie & 1284,4 & 77,5 & 2,5 & 15,7 & 3,3 & 1,0 & 402,3 & 97,3 & 2,7 \\
\hline Małopolskie & 922,7 & 71,2 & 3,1 & 20,7 & 4,3 & 0,7 & 464,0 & 95,0 & 5,0 \\
\hline Mazowieckie & 2385,1 & 69,9 & 3,9 & 21,9 & 3,4 & 0,9 & 881,0 & 94,1 & 5,9 \\
\hline Opolskie & 600,1 & 81,8 & 0,5 & 14,2 & 2,1 & 1,4 & 263,0 & 98,5 & 1,5 \\
\hline Podkarpackie & 937,2 & 64,4 & 1,1 & 29,2 & 4,2 & 1,1 & 728,7 & 94,0 & 6,0 \\
\hline Podlaskie & 1214,1 & 63,4 & 0,4 & 32,9 & 2,6 & 0,7 & 643,8 & 97,9 & 2,1 \\
\hline Pomorskie & 920,2 & 76,2 & 0,5 & 19,8 & 2,2 & 1,3 & 690,5 & 98,8 & 1,2 \\
\hline Śląskie & 628,3 & 72,5 & 1,0 & 21,9 & 2,9 & 1,7 & 412,6 & 97,7 & 2,3 \\
\hline Świętokrzyskie & 751,6 & 72,3 & 4,3 & 18,5 & 3,9 & 1,0 & 345,9 & 96,9 & 3,1 \\
\hline Warmińsko-mazurskie & 1306,7 & 67,2 & 0,2 & 29,6 & 2,0 & 1,0 & 796,1 & 96,9 & 3,1 \\
\hline Wielkopolskie & 1935,7 & 78,3 & 0,8 & 14,0 & 5,7 & 1,2 & 797,1 & 98,7 & 1,3 \\
\hline Zachodniopomorskie & 1119,2 & 77,0 & 0,4 & 20,1 & 1,6 & 0,9 & 857,3 & 97,4 & 2,6 \\
\hline
\end{tabular}

Źródło: opracowanie własne na podstawie danych Rocznika statystycznego rolnictwa (2015).

(łąk i pastwisk trwałych, sadów, upraw mieszanek motylkowato-trawiastych i traw, rowów i stawów) i ziemi nierolniczej (lasów, gruntów zadrzewionych i zakrzewionych, wód i użytków ekologicznych) oraz sumy powierzchni niekorzystnych (niestabilnych ekologicznie) elementów ziemi rolniczej (gruntów ornych z zasiewami jednorocznymi, gruntów rolnych zabudowanych) i nierolniczej (gruntów zabudowanych i zurbanizowanych, nieużytków i innych terenów), charakteryzuje się jedynie województwo lubuskie. Najniższym wskaźnikiem stabilności ekologicznej powierzchni ziemi charakteryzują się województwa łódzkie i kujawsko-pomorskie (ryc. 3). Funkcjonujący (zwłaszcza na gruntach po byłych PGR) system gospodarki wielkoobszarowej z monokulturami roślin i uproszczonym płodozmianem oraz prowadzona często w niewłaściwy sposób agrotechnika, wyzwalają procesy erozyjne, które przyczyniają się do zmniejszenia zawartości glebowej materii organicznej i zbyt sła- 
bego wiązania (sekwestracji) węgla w glebie (Koćmit 1998; Wojtasik i in. 2008). Rozwojowi gospodarki niskoemisyjnej na obszarach wiejskich w Polsce nie sprzyja także niewielka liczba biogazowni rolniczych w stosunku do wysokiego potencjału pozyskiwania biomasy. Na koniec marca 2016 r. produkcją biogazu rolniczego w Polsce zajmowało się 76 podmiotów gospodarczych, wytwarzających energię elektryczną w układzie kogeneracyjnym w 86 instalacjach o rocznej wydajności do wytwarzania biogazu rolniczego na poziomie 349,8 mln $\mathrm{m}^{3}$ oraz łącznej mocy zainstalowanej elektrycznej 91,1 MW (Rejestr wytwórców biogazu... 2016). Najwięcej biogazowni rolniczych zlokalizowanych jest w województwie zachodniopomorskim, gdzie funkcjonuje 12 instalacji o łącznej mocy zainstalowanej elektrycznej 11,6 MW Dla porównania, w województwach opolskim i świętokrzyskim zlokalizowano po jednej tego typu instalacji o mocy 2,0 i 0,8 $\mathrm{MW}_{\mathrm{e}}$. Sukcesywny spadek pogłowia trzody chlewnej ogranicza z kolei możliwość wykorzystania obornika jako alternatywy dla nawozów azotowych. Według danych GUS w latach 2005-2015 pogłowie trzody chlewnej w Polsce zmniejszyło się o ok. 40\%.

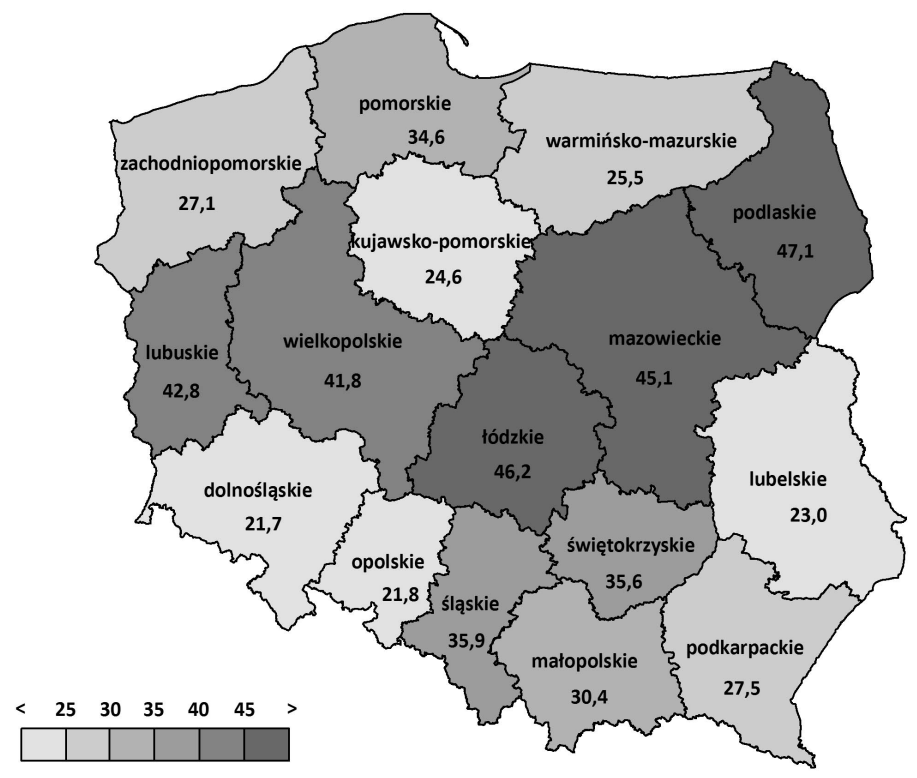

Ryc. 1. Udział gleb ornych słabych i najsłabszych w Polsce w 2008 r.

Źródło: opracowanie własne na podstawie: P. Skłodowski i A. Bielska (2009).

Percentage of weak and very weak soils in Poland in 2008

Source: own elaboration based on: P. Skłodowski and A. Bielska (2009). 


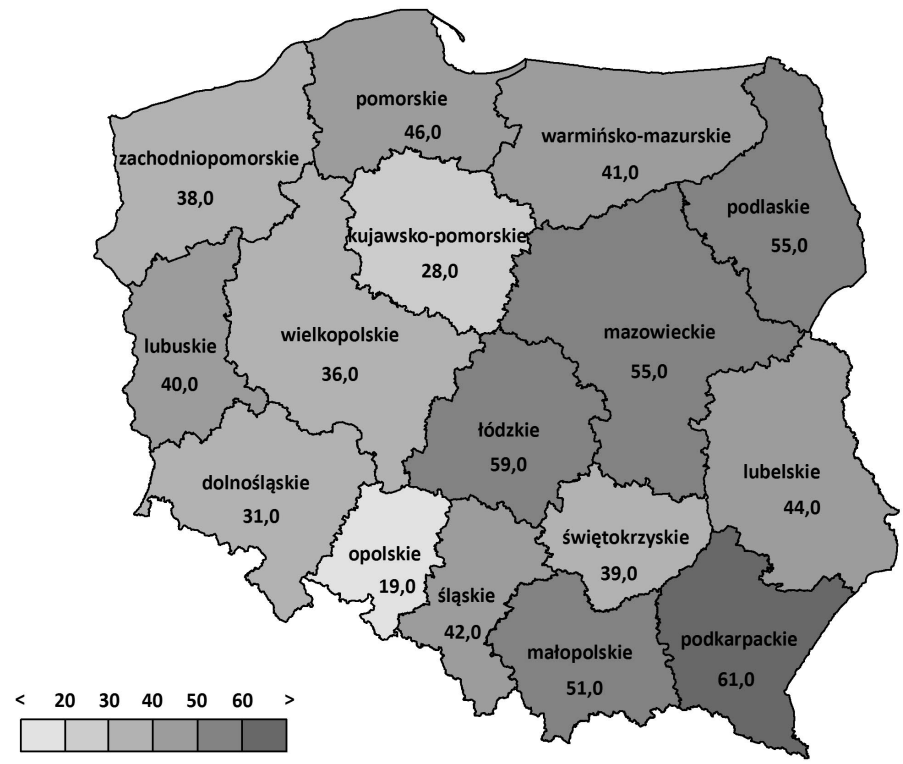

Ryc. 2. Udział gleb kwaśnych i bardzo kwaśnych w użytkach rolnych w Polsce w 2015 r. Źródło: opracowanie własne na podstawie danych GUS (2015b).

Percentage of acidic and very acidic soils in agricultural areas in Poland in 2015

Source: own elaboration based on CSO (2015b) data.

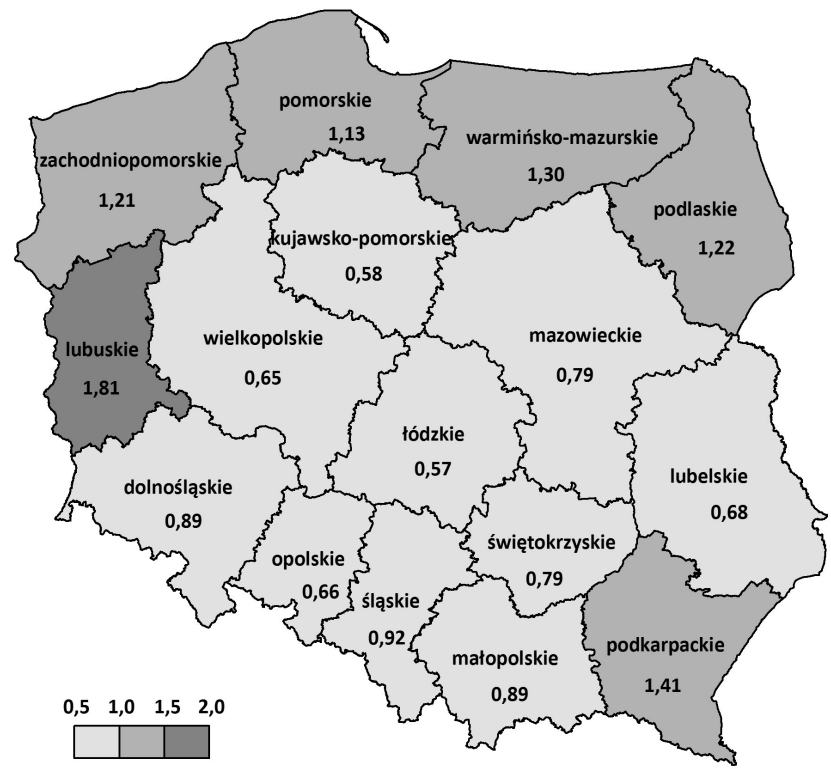

Ryc. 3. Wartości wskaźnika stabilności ekologicznej powierzchni ziemi w Polsce w 2014 r.: 0,5-1,0 - niski, 1,01-1,5 - średni, 1,51-2,0 - wysoki.

Źródło: opracowanie własne na podstawie: A. Harasim (2015).

Values of ecological stability indicator in the land use in Poland in 2014: 0.5-1.0-low, 1.01-1.5 - medium, 1.51-2.0-high.

Source: own elaboration based on: A. Harasim (2015). 
Szans na utrzymanie lub wzrost zdolności do pochłaniania $\mathrm{CO}_{2}$ oraz ograniczenie emisji z rolnictwa i gleb w oparciu o zasoby obszarów wiejskich upatrywać należy przede wszystkim w zakładanym wzroście znaczenia upraw roślin o dodatnim wskaźniku reprodukcji glebowej materii organicznej (strączkowych, traw, bobowatych i ich mieszanek) oraz międzyplonów, związanym z systemem płatności bezpośrednich w latach 2015-2020 oraz promowaniem zrównoważonego systemu gospodarowania i zapobiegania ubytkowi substancji organicznej w glebie w ramach Programu Rozwoju Obszarów Wiejskich na lata 2014-2020 (PROW, 2014). Wzrasta także zainteresowanie biogazowniami rolniczymi, co powinno przyczynić się do zwiększenia stopnia zagospodarowania odchodów zwierzęcych i innych odpadów rolniczych oraz wpłynąć na rozwój upraw roślin z przeznaczeniem na substraty. W rejestrze wytwórców biogazu rolniczego Agencji Rynku Rolnego w okresie od stycznia 2011 r. do marca 2016 r., pojawiły się 72 nowe podmioty gospodarcze oraz 78 nowych instalacji. Szans należy upatrywać również w realizacji przez Państwowe Gospodarstwo Leśne Lasy Państwowe (w którego zarządzie pozostaje 77,1\% powierzchni leśnej kraju) koncepcji wielofunkcyjnego modelu lasu, ze szczególnym uwzględnieniem jego roli ekologicznej (ochronnej), a także w realizowanych koncepcjach wyznaczania sieci korytarzy ekologicznych (m.in. na potrzeby planowania przestrzennego).

Do głównych zagrożeń w zakresie możliwości utrzymania lub wzrostu zdolności do pochłaniania $\mathrm{CO}_{2}$ oraz ograniczenia emisji gazów cieplarnianych z rolnictwa i gleb należy wzrost ryzyka wystąpienia suszy rolniczej, obserwowany już niemal na 95\% powierzchni rolniczej Polski. Szczególnie zagrożone są bardzo lekkie i lekkie gleby piaszczyste o niskiej zdolności retencjonowania wody w profilu. Ograniczony dostęp do wody może okazać się istotną barierą zarówno dla produkcji żywności, jak i rozwoju zielonych technologii. Rośliny energetyczne charakteryzują się bowiem zróżnicowanymi wymaganiami wodnymi i reakcją na ich zaspokojenie w środowisku glebowym (Ostrowski i in. 2009). Nasilają się także czynniki stresowe oddziałujące na uprawy i środowisko leśne, w szczególności występujące coraz częściej w Polsce anomalie pogodowe oraz zjawiska ekstremalne. Mogą one przyczynić się m.in. do większego nasilenia chorób i gradacji szkodników roślin, trudności w terminowym i precyzyjnym wykonywaniu zabiegów agrotechnicznych, bezpośrednich zniszczeń roślin lub plonu w fazie dojrzewania, przyspieszenia procesów erozji gleb, znacznych ograniczeń plonowania, a także chorób infekcyjnych i pożarów lasów. Wśród innych zagrożeń wymienić należy pogarszające się warunki wodne w glebach leśnych i często niewłaściwą strukturę drzewostanów (niezgodność z siedliskiem). Systematycznie zmniejsza się powierzchnia użytków rolnych. W skali kraju w latach 2002-2010 ich areał zmniejszył się o 8\% (1,4 mln ha). Szczególnie duży spadek powierzchni użytków rolnych w tym okresie (o 14-16\%) zanotowano w województwach śląskim, małopolskim i podkarpackim (Matyka 2012). Wzrasta natomiast zużycie nawozów azotowych fizjologicznie kwaśnych, co może - zwłaszcza przy niedostatecznych dawkach ekologicznych i naturalnych nawozów zawierających wapń - przyczynić się do dalszego wzrostu zakwaszenia gleb. Obserwuje się także tendencję do specjalizacji gospodarstw w kierunku oddzielenia produkcji roślinnej od zwierzęcej, mogącą skutkować wyłączeniem stosowania obornika w gospodarstwach bezinwentarzowych z jednoczesnym brakiem praktyk sekwestrujących węgiel. Zmniejszająca się opłacalność produkcji oraz wzrost kosztów chowu zwierząt gospodarskich przyczyniają się do spadku zainteresowania dalszym prowadzeniem gospodarstw rolnych wśród coraz lepiej wykształconej (również w zakresie rolnictwa) młodzieży. 


\section{Kierunki rozwoju niskowęglowego lokalnych samorządów w oparciu o zasoby obszarów wiejskich - przykład powiatu starogardzkiego}

Mając na uwadze uwarunkowania wynikające z powyższej diagnozy, w celu skutecznego kształtowania gospodarki niskoemisyjnej na obszarach wiejskich, należy dążyć przede wszystkim do pełnego wykorzystania zasobów i potencjału tych obszarów dla wzrostu sekwestracji węgla w biomasie i glebie, wnoszenia materii organicznej do gleby z jednoczesnym zmniejszaniem jej strat, optymalizacji systemów przechowywania, transportu i rozprowadzania na polach odchodów zwierzęcych oraz ich odpowiedniego zagospodarowania, szerokiego wykorzystywania działalności rolniczej i przetwórstwa rolno-spożywczego do rozwoju energetyki odnawialnej (w tym do produkcji biogazu i biopaliw), a także do znaczącej poprawy efektywności energetycznej oraz wzrostu udziału energii odnawialnej w produkcji roślinnej i zwierzęcej.

Realizacja wyżej wymienionych celów wymaga wdrożenia odpowiednich zasad funkcjonowania gospodarki niskoemisyjnej oraz kierunków rozwoju niskowęglowego obszarów wiejskich. Przedstawione poniżej propozycje są efektem badań i analiz przeprowadzonych podczas prac autora nad Pilotażowym programem niskowęglowego rozwoju powiatu starogardzkiego, zrealizowanym w latach 2014-2015 w ramach projektu „Dobry Klimat dla Powiatów" przez Instytut na rzecz Ekorozwoju, Związek Powiatów Polskich oraz Community Energy Plus we współpracy ze społeczeństwem, władzami i instytucjami powiatu starogardzkiego. Jest to pierwszy tego typu dokument poświęcony gospodarce niskoemisyjnej, sporządzony w skali powiatu w Polsce. Rolnictwo oraz tereny wiejskie (wraz z leśnymi) stanowią jeden z jego podstawowych obszarów aktywności oraz istotną oś rozwoju (Pilotażowy program... 2015). Wyniki prac nad Pilotażowym programem niskowęglowego rozwoju powiatu starogardzkiego, ze względu na regionalne zróżnicowanie struktur wiejskich i rolniczych w Polsce (Bański 2010), nie mogą być uogólniane na skalę ogólnokrajową. Mając jednak na uwadze typowo rolniczy charakter analizowanego obszaru, położonego w południowej części województwa pomorskiego, są one reprezentatywne dla większości terenów wiejskich znajdujących się w niżowej części kraju. Wśród 13 gmin wchodzących w skład badanego powiatu, 9 to gminy wiejskie. Na jego terenie znajduje się ok. 3,5 tys. gospodarstw rolnych, zarejestrowanych jest także 367 podmiotów gospodarczych zajmujących się rolnictwem, leśnictwem, łowiectwem i rybactwem. Jak wynika z obliczeń śladu węglowego, rolnictwo jest źródłem ok. 12\% całkowitej emisji gazów cieplarnianych w tym powiecie (tab. 2). W latach 2005-2013 zanotowano tu wzrost o ok. 9,7\% emisji metanu i podtlenku azotu pochodzących z rolnictwa, wyrażonej jako ekwiwalent dwutlenku węgla ( $\mathrm{CO}_{2}$ eq). Większość emisji z tego sektora (ok. 54\% w 2013 r.) pochodzi ze źródeł związanych z hodowlą zwierząt gospodarskich - fermentacji jelitowej oraz odchodów zwierzęcych (tab. 3). Jej istotnym źródłem jest również użytkowanie gleb rolnych, w szczególności stosowanie nawozów mineralnych. Według prognozy ostrzegawczej, w przypadku braku podjęcia dodatkowych działań na rzecz redukcji emisji, mając na uwadze zmieniające się uwarunkowania rynkowe, zmiany w polityce rolnej, trendy zmian w pogłowiu zwierząt, nieprzewidywalność cen pasz oraz podaży i popytu, potencjalną koniunkturę, a także zachodzące zmiany strukturalne na wsi, wielkość emisji z rolnictwa w powiecie starogardzkim w 2020 r. wzrośnie o 7,1\%, a w 2030 r. o 19,5\% w stosunku do stanu z 2013 r. 
Tabela 2. Całkowita emisja gazów cieplarnianych w powiecie starogardzkim w latach: 2005, 2010, 2013 oraz prognoza ostrzegawcza na lata 2020 i 2030

\begin{tabular}{|l|c|c|c|c|c|}
\hline \multirow{2}{*}{ Źródło emisji } & \multicolumn{2}{c|}{$\begin{array}{c}\text { Całkowita emisja } \\
\text { (tys. Mg CO eq) }\end{array}$} & \multicolumn{2}{c|}{$\begin{array}{c}\text { Prognozowana } \\
\text { emisja } \\
\text { (tys. Mg CO eq) }\end{array}$} \\
\cline { 2 - 6 } & $\mathbf{2 0 0 5}$ & $\mathbf{2 0 1 0}$ & $\mathbf{2 0 1 3}$ & $\mathbf{2 0 2 0}$ & $\mathbf{2 0 3 0}$ \\
\hline Przemyst, energetyka i gospodarka mieszkaniowa & 855,0 & 784,4 & 705,7 & 781,7 & 810,9 \\
Transport & 80,9 & 120,1 & 160,5 & 195,4 & 249,0 \\
Gospodarka odpadami i proces oczyszczania ścieków & 314,7 & 367,7 & 400,8 & 479,8 & 565,5 \\
Rolnictwo & 120,3 & 124,0 & 132,0 & 141,4 & 157,7 \\
\hline Razem & 1370,9 & 1396,2 & 1399,0 & 1598,3 & 1783,1 \\
\hline
\end{tabular}

Źródło: opracowanie własne na podstawie: Pilotażowy program... (2015).

Tabela 3. Emisja gazów cieplarnianych z rolnictwa w powiecie starogardzkim w latach: 2005, 2010, 2013 oraz prognoza ostrzegawcza na latach 2020 i 2030

\begin{tabular}{|l|r|r|r|r|r|}
\hline \multirow{2}{*}{\multicolumn{1}{|c|}{ Źródło emisji }} & \multicolumn{3}{c|}{$\begin{array}{c}\text { Całkowita emisja } \\
\text { (Mg CO } \mathbf{2} \text { eq) }\end{array}$} & \multicolumn{2}{c|}{$\begin{array}{c}\text { Prognozowana emisja } \\
\text { (Mg CO } \mathbf{~ e q ) ~}\end{array}$} \\
\cline { 2 - 6 } & $\mathbf{2 0 0 5}$ & $\mathbf{2 0 1 0}$ & $\mathbf{2 0 1 3}$ & $\mathbf{2 0 2 0}$ & $\mathbf{2 0 3 0}$ \\
\hline Fermentacja jelitowa & 23511,10 & 22958,09 & 24157,18 & 24259,20 & 25057,20 \\
Odchody zwierzęce & 47691,43 & 50379,52 & 47748,95 & 49424,80 & 49964,80 \\
Grunty rolne & 49131,45 & 50637,29 & 60058,52 & 67735,00 & 82615,00 \\
Spalanie resztek roślinnych & 14,50 & 15,75 & 16,11 & 18,00 & 20,13 \\
\hline Razem & 120348,48 & 123990,65 & 131980,76 & 141437,01 & 157657,13 \\
\hline
\end{tabular}

Źródło: opracowanie własne na podstawie: Raport /l oceny... (2015).

W porównaniu z prognozą ostrzegawczą, jeśli podjęte będą określone działania, możliwe jest ograniczenie wzrostu emisji gazów cieplarnianych ze źródeł rolniczych w powiecie starogardzkim o niecałe 15 tys. $\mathrm{Mg} \mathrm{CO}_{2}$ eq w 2020 r. i o ponad 23 tys. $\mathrm{Mg} \mathrm{CO}_{2}$ eq w 2030 r. Możliwa jest również poprawa zdolności pochłaniania $\mathrm{CO}_{2}$ o ponad 36\% w okresie 2005-2020 i o ponad 65\% w okresie 2005-2030 w wyniku zmian w użytkowaniu terenów. Aby osiągnąć wskazane wartości zmniejszenia emisji oraz wzrostu pochłaniania $\mathrm{CO}_{2}$, mając na uwadze lokalne uwarunkowania, konieczne jest wdrożenie odpowiednich zasad funkcjonowania gospodarki niskowęglowej na terenach wiejskich powiatu, w oparciu o ich zasoby. Przyjęto, że powinny one w szczególności obejmować zagospodarowywanie do produkcji energii niewykorzystywanych w gospodarstwie rolnym odpadów organicznych pochodzących z działalności rolniczej, a także stosowanie i promocję dobrych praktyk oraz niskoemisyjnych technologii w sektorze rolno-spożywczym. Istotną rolę powinna odgrywać promocja innowacyjnych, niskoemisyjnych technologii w produkcji, stosowaniu nawozów i środków ochrony roślin, nowych odmian (w tym roślin energetycznych), systemów chowu i żywienia zwierząt oraz zabiegów agrotechnicznych. Konieczne jest planowanie i skuteczne zarządzanie przeciwerozyjną ochroną gleb z wykorzystaniem dokumentów planistycznych i strategicznych, stosowanie agrotechniki przeciwerozyjnej oraz fitomelioracji na terenach zagrożonych erozją, zwiększenie retencyjności gleb na obszarach wiejskich w zintegrowanej ochronie przed powodzią, erozją i skutkami suszy, dalsze zwiększanie powierzchni terenów zielonych i lesistości 
oraz wprowadzanie zadrzewień i tworzenie leśnych korytarzy ekologicznych. W produkcji roślinnej należy dążyć do stosowania międzyplonów i wsiewek roślin o dodatnim wskaźniku reprodukcji glebowej materii organicznej, przyorywania i stosowania jako zielony nawóz resztek pożniwnych pozostających na polu oraz kompostowania i wykorzystywania do nawożenia wysokowartościowym kompostem produktów ubocznych chowu zwierząt. W produkcji zwierzęcej wskazane jest eliminowanie w karmieniu zwierząt zbędnych ilości aminokwasów oraz stosowanie preparatów wiążących związki azotowe.

Wśród podstawowych kierunków rozwoju niskowęglowego terenów wiejskich powiatu powinny znaleźć się m.in.: zwiększenie wykorzystania przez rolników obornika i nawozów organicznych (m.in. kompostów i przyorywania nawozów zielonych), wzrost znaczenia w produkcji roślin o dodatnim wskaźniku reprodukcji glebowej materii organicznej oraz wykorzystywanie gruntów ugorowanych lub odłogowanych i nieużytków pod uprawę roślin energetycznych. Na terenach o słabych glebach piaszczystych, podatnych na erozję konieczna jest dalsza realizacja zalesień i zadrzewień, a także wzmacnianie odporności lasów poprzez odpowiednią pielęgnację nowo założonych upraw leśnych, wprowadzanie gatunków domieszkowych i biocenotycznych w zalesieniach oraz zapobieganie fragmentacji kompleksów leśnych. Na obszarach, na których występują wtórnie nasadzone monokultury sosnowe należy realizować systematyczną przebudowę drzewostanów w celu poprawy warunków wodnych gleb oraz funkcji glebochronnych i glebotwórczych. Konieczne są działania prowadzące do zwiększenia sekwestracji węgla w glebie, w szczególności przez przeciwdziałanie erozji oraz dążenie do zachowania właściwej struktury i zasobności gleby w składniki nawozowe. W celu zmniejszenia zakwaszenia gleb użytkowanych rolniczo, na obszarach o glebach kwaśnych i bardzo kwaśnych powinno stosować się wapnowanie gleb.

Wśród działań mających na celu wnoszenie materii organicznej do gleby z jednoczesnym zmniejszaniem jej strat, niezbędnych do realizacji we wszystkich gminach powiatu, szczególną rolę powinno odgrywać zwiększenie produkcji biomasy, stosowanie nawozów organicznych, wprowadzanie użytków zielonych oraz stosowanie odpowiednich praktyk rolniczych, takich jak mulczowanie, orka zachowawcza lub brak orki, utrzymywanie pokrywy roślinnej gleby lub pozostawienie na niej resztek roślinnych.

Konieczny jest wzrost zainteresowania rolników poprawą technik żywienia zwierząt, odpowiednim zbilansowaniem dawek pokarmowych i dodawaniem do paszy preparatów wiążących związki azotowe, a także stosowaniem płyt obornikowych i zbiorników na gnojowicę, doskonaleniem systemów utrzymania zwierząt gospodarskich oraz obniżaniem emisji metanu z przechowywanych obornika i gnojowicy w wyniku obniżenia temperatury składowanych odchodów przez odzysk i kumulację energii cieplnej czy budowę instalacji do odzysku biogazu z fermentacji gnojowicy.

Ukierunkowanie rozwoju terenów wiejskich na gospodarkę niskoemisyjną wymaga realizacji określonych inwestycji, działań miękkich i instytucjonalnych. W przypadku powiatu starogardzkiego szczególne znaczenie powinny odgrywać:

- budowa małych biogazowni rolniczych przez rolników indywidualnych (w formie sieci);

- promocja i wdrażanie inteligentnych technik rolnictwa precyzyjnego w zrównoważonej produkcji roślinnej, nowych technologii produkcji, stosowania nawozów naturalnych, mineralnych i środków ochrony roślin, a także nowych odmian roślin, technik hodowlanych i zabiegów agrotechnicznych w warunkach zmian klimatycznych; 
- realizacja szkoleń dla rolników w zakresie gospodarki niskoemisyjnej na terenach wiejskich oraz stosowania odnawialnych źródeł energii w rolnictwie w ramach działalności doradczej Ośrodków Doradztwa Rolniczego;

- wdrożenie do realizacji w działającej na terenie powiatu szkole rolniczej programu nauczania dodatkowego przedmiotu „Odnawialne źródła energii” oraz kształcenie w zawodzie technik urządzeń i systemów energetyki odnawialnej.

Podstawową rolę w monitorowaniu skuteczności realizacji działań mających na celu kształtowanie niskowęglowego rozwoju - zarówno powiatu starogardzkiego, jak i innych powiatów i gmin - powinny pełnić przyjęte w PGN mierniki, pogrupowane przy zastosowaniu powszechnie wykorzystywanej koncepcji podziału mierników środowiskowych na trzy grupy funkcjonalne: presji na środowisko, jakości (stanu środowiska) oraz reakcji na problemy sozologiczne, przejawiającej się działaniami w zakresie ochrony środowiska (Borys 2005; Kistowski 2006). W celu skutecznego prowadzenia monitoringu emisji zanieczyszczeń pochodzących z produkcji roślinnej i zwierzęcej, stanu środowiska oraz skuteczności realizacji kierunków rozwoju niskowęglowego na obszarach wiejskich, wskazane jest wykorzystanie przynajmniej podstawowych mierników, traktowanych jako zakres minimum (tab. 4).

Podstawowym źródłem danych, z którego samorządy mogą pozyskać zmienne i na ich podstawie budować moduł wskaźnikowy jest Bank Danych Lokalnych Głównego Urzędu Statystycznego (BDL GUS). Na poziomie gmin dostępne są w nim wyniki Powszechnych Spisów Rolnych, obejmujące m.in. liczbę indywidualnych gospodarstw rolnych prowadzących produkcję zwierzęcą, liczbę ciągników i maszyn rolniczych, powierzchnię i strukturę użytków rolnych (w tym upraw wieloletnich i trwałych użytków zielonych), wielkość i strukturę produkcji zwierzęcej, powierzchnię i strukturę zasiewów (w tym roślin bobowatych), poziom zużycia nawozów mineralnych i organicznych, powierzchnię obszarów leśnych i wskaźnik lesistości oraz powierzchnię gruntów ugorowanych. W statystyce publicznej znaleźć można również dane dotyczące powierzchni oraz liczby nowych nasadzeń i ubytków drzew i krzewów. Agencja Rynku Rolnego prowadzi ogólnodostępny rejestr wytwórców biogazu rolniczego, na podstawie którego można określić liczbę i moc uruchomionych jednostek wytwarzania energii elektrycznej i cieplnej z biomasy i biogazu w gminie w danym roku. Instytut Uprawy Nawożenia i Gleboznawstwa w Puławach dysponuje stosunkowo dokładnymi danymi dotyczącymi stopnia zagrożenia erozją użytków rolnych w gminach. Lokalne samorządy mogą także korzystać z możliwych do zastosowania na poziomie gminy wskaźników, zaproponowanych w istniejących opracowaniach. Wśród ciekawych pozycji wymienić należy m.in. Atlas Rolnictwa Polski, przedstawiający obraz stanu polskiej gospodarki rolnej w ujęciu przestrzennym o różnych skalach (Bański 2010), pracę P. Śleszyńskiego i in. (2013), w której dokonano przeglądu dostępnych źródeł informacji i przedstawiono koncepcję wskaźników (w tym środowiskowych) do oceny zagospodarowania i ładu przestrzennego w gminach, a także Atlas sozologiczny gmin Polski, poświęcony problematyce zagrożeń, jakości i ochrony środowiska, w tym elementów rolniczej przestrzeni produkcyjnej (Kistowski 2013). 
Tabela 4. Przykłady mierników, możliwych do zastosowania w celu monitorowania skuteczności działań na rzecz niskowęglowego rozwoju obszarów wiejskich

\begin{tabular}{|c|c|}
\hline & Miernik \\
\hline $\begin{array}{l}\text { Mierniki presji } \\
\text { na środowisko }\end{array}$ & $\begin{array}{l}\text { liczba indywidualnych gospodarstw rolnych prowadzących produkcję zwierzęcą [szt.] } \\
\text { udział użytkowanych rolniczo gleb narażonych na erozję w stosunku do ogółu gleb narażo- } \\
\text { nych na erozję [\%] } \\
\text { liczba ciągników i maszyn rolniczych [szt., szt./100 ha] } \\
\text { powierzchnia użytków rolnych przypadająca na } 1 \text { ciągnik [ha/ciągnik] } \\
\text { produkcja zwierzęca na } 1 \text { ha użytków rolnych [kg/ha, dm³/ha] } \\
\text { zużycie nawozów mineralnych na } 1 \text { ha użytków rolnych [kg/ha] } \\
\text { zużycie nawozów wapniowych na } 1 \text { ha użytków rolnych [kg/ha] }\end{array}$ \\
\hline $\begin{array}{l}\text { Mierniki } \\
\text { jakości (stanu } \\
\text { środowiska) }\end{array}$ & $\begin{array}{l}\text { lesistość gminy/powiatu [\%] } \\
\text { udział użytków rolnych zagrożonych erozją [\%] } \\
\text { udział gruntów ugorowanych w stosunku do powierzchni użytków rolnych [\%] }\end{array}$ \\
\hline Mierniki reakcji & $\begin{array}{l}\text { powierzchnia nowych zalesień, zadrzewień i zakrzewień [ha lub\%] } \\
\text { liczba ekologicznych gospodarstw rolnych [szt.] } \\
\text { udział powierzchni użytków rolnych w gospodarstwach ekologicznych w stosunku do are- } \\
\text { ału użytków rolnych [\%] } \\
\text { powierzchnia upraw wieloletnich [ha] } \\
\text { zużycie nawozów organicznych (obornika) na } 1 \text { ha użytków rolnych [kg/ha] } \\
\text { udział powierzchni upraw ekologicznych w stosunku do powierzchni użytków rolnych [\%] } \\
\text { udział powierzchni upraw roślin strączkowych w stosunku do powierzchni użytków rolnych } \\
\text { [\%] } \\
\text { udział trwałych użytków zielonych w stosunku do powierzchni użytków rolnych [\%] } \\
\text { liczba uruchomionych jednostek wytwarzania energii elektrycznej i cieplnej z biomasy } \\
\text { i biogazu [szt.] } \\
\text { moc uruchomionych jednostek wytwarzania energii elektrycznej i cieplnej z biomasy } \\
\text { i biogazu [kW, MW] }\end{array}$ \\
\hline
\end{tabular}

\section{Podsumowanie}

Rolnictwo i obszary wiejskie - w przeciwieństwie do obecnych tendencji - powinny stanowić istotny element w lokalnym kształtowaniu gospodarki niskoemisyjnej oraz kluczowy obszar aktywności w opracowywanych aktualnie lokalnych planach na rzecz jej rozwoju. Określenie głównych kierunków rozwoju niskowęglowego, kluczowych potrzeb inwestycyjnych oraz konkretnych działań w części programowej planów gospodarki niskoemisyjnej, powinno być poprzedzone pełną diagnozą lokalnych uwarunkowań, obejmującą również ocenę sytuacji rolnictwa i obszarów wiejskich oraz możliwości wykorzystania ich zasobów w celu utrzymania lub wzrostu zdolności do pochłaniania $\mathrm{CO}_{2}$ i ograniczenia emisji gazów cieplarnianych z rolnictwa i gleb.

Przeprowadzona w artykule analiza oraz wyniki wcześniejszych prac autora nad Pilotażowym programem... (2015), wskazują na duży potencjał rolnictwa i obszarów wiejskich (w tym 
leśnych) w zakresie możliwości wykorzystania ich zasobów w celu zwiększenia sekwestracji węgla w biomasie i glebie, ograniczenia emisji gazów cieplarnianych, a także wykorzystania działalności rolniczej i przetwórstwa rolno-spożywczego wraz z biomasą drzewną do rozwoju energetyki odnawialnej, w tym do produkcji biogazu i biopaliw. W świetle przeprowadzonej oceny mocnych i słabych stron w zakresie możliwości utrzymania lub wzrostu zdolności do pochłaniania $\mathrm{CO}_{2}$ oraz ograniczenia emisji z terenów wiejskich i związanej z nimi działalności rolniczej, największym potencjałem w tym zakresie charakteryzują się województwa: zachodniopomorskie, warmińsko-mazurskie, podlaskie, wielkopolskie i lubuskie.

Potencjał ten, oparty przede wszystkim na dużych zasobach użytków rolnych i gruntów leśnych, powinien być kształtowany i wzbogacany poprzez wdrożenie odpowiednich zasad funkcjonowania oraz kierunków rozwoju gospodarki niskowęglowej na obszarach wiejskich. Przykład powiatu starogardzkiego wskazuje, że należy dążyć do identyfikacji i eliminacji słabych stron oraz potencjalnych zagrożeń utrudniających utrzymanie lub wzrost zdolności do pochłaniania $\mathrm{CO}_{2}$ oraz ograniczenie emisji gazów cieplarnianych z rolnictwa i gleb przy jednoczesnej realizacji wizji gospodarki niskoemisyjnej na tych obszarach. W promocji i wdrażaniu niskowęglowych praktyk rolniczych należy wykorzystać potencjał systemu doradztwa rolniczego, a także szkół rolniczych, realizując w nich treści programowe z zakresu odnawialnych źródeł energii oraz kształcąc w zawodzie technik urządzeń i systemów energetyki odnawialnej.

\section{Literatura}

Bański J. (red.), 2010, Atlas rolnictwa Polski, Instytut Geografii i Przestrzennego Zagospodarowania im. Stanisława Leszczyckiego PAN, Warszawa.

Borys T., 2005, Wskaźniki zrównoważonego rozwoju, Wydawnictwo Ekonomia i Środowisko, Warszawa-Białystok.

Gaweł E., 2011, Rola roślin motylkowatych drobnonasiennych w gospodarstwie rolnym, Woda-Środowisko-Obszary Wiejskie, 11, 3 (35), s. 73-91.

Harasim A., 2015, Użytkowanie powierzchni ziemi w Polsce w aspekcie stabilności ekologicznej, Roczniki Naukowe Stowarzyszenia Ekonomistów Rolnictwa i Agrobiznesu, 1, s. 66-71.

Kistowski M., 2006, Wpływ programów ochrony na środowisko przyrodnicze. Ocena jakości i ekoinnowacyjności programów ochrony środowiska województw opracowanych w latach 2001-2005, Studia nad Zrównoważonym Rozwojem, t. 3, Komitet „CZłowiek i Środowisko” PAN, Gdańsk-Warszawa.

Kistowski M., 2013, Atlas sozologiczny gmin Polski 2000-2009, Wydawnictwo Uniwersytetu Gdańskiego, Gdańsk.

Koćmit A., 1998, Erozja wodna w obszarach młodoglacjalnych Pomorza i możliwości jej ograniczenia, Bibliotheca Fragmenta Agronomica, 4B, s. 83-99.

Kozłowski S., Swędrzyński A., Zielewicz W., 2011, Rośliny motylkowate w środowisku przyrodniczym, Woda-Środowisko-Obszary Wiejskie, 11, 4 (36), s. 161-181.

Matyka M., 2012, Analiza regionalnego zróżnicowania zmian w użytkowaniu gruntów w Polsce, Polish Journal of Agronomy, 10, s. 16-20.

Ostrowski J., Gutkowska A., Tusiński E., 2009, Udział czynnika wodnego w modelowaniu kategoryzacji oraz oceny przydatności gruntów do uprawy roślin energetycznych, Woda-ŚrodowiskoObszary Wiejskie, 9, 4 (28), s. 187-202. 
Pilotażowy program niskowęglowego rozwoju powiatu starogardzkiego, 2015, Fundacja Instytut na rzecz Ekorozwoju, Warszawa.

Polna M., 2005, Zmiany lesistości Polski w latach 1990-2001, Acta Sci. Pol. Silv. Colendar. Rat. Ind. Lignar., 4 (1), s. 51-60.

PROW, 2014, Program Rozwoju Obszarów Wiejskich na lata 2014-2020, Ministerstwo Rolnictwa i Rozwoju Wsi, Warszawa.

Raport Il oceny śladu węglowego powiatu starogardzkiego dla lat 2005, 2010 i 2013 oraz prognoza ostrzegawcza na lata 2020 i 2030, 2015, Fundacja Instytut na rzecz Ekorozwoju, Warszawa.

Rejestr wytwórców biogazu rolniczego (stan na dzień 30.03.2016 r.), 2016, Agencja Rynku Rolnego, Warszawa.

Rocznik statystyczny rolnictwa, 2015, GUS, Warszawa.

Skłodowski P., Bielska A., 2009, Właściwości i urodzajność gleb Polski - podstawq kształtowania relacji rolno-środowiskowych, Woda-Środowisko-Obszary Wiejskie, 9, 4 (28), s. 203-214.

Szczegółowe zalecenia dotyczqce struktury planu gospodarki niskoemisyjnej, 2013, Narodowy Fundusz Ochrony Środowiska i Gospodarki Wodnej, Warszawa.

Śleszyński P. (red.), 2013, Wskaźniki zagospodarowania i ładu przestrzennego w gminach, Biuletyn KPZK PAN, 252, Warszawa

Środki produkcji w rolnictwie w roku gospodarczym 2014/2015, 2015, GUS, Warszawa.

Transformacja w kierunku gospodarki niskoemisyjnej w Polsce, 2011, Bank Światowy, Washington DC.

Wojtasik M., Wiśniewski P., Loranc L., 2008, Problemy erozji gleb na przykładzie kilku gmin w województwach kujawsko-pomorskim i wielkopolskim, Przegląd Naukowy Inżynieria i Kształtowanie Środowiska, 3 (41), s. 41-49.

\section{Summary}

The aim of the study is to assess the importance of rural resources and the ability to use their potential for the local low-carbon economy development. The paper presents a diagnosis of the situation of Polish agriculture and rural areas in terms of low-carbon economy. Strengths and weaknesses as well as the opportunities and threats in the two key elements, i.e. maintenance or increase in the ability to absorb $\mathrm{CO} 2$ and reduction of greenhouse gas emissions from agricultural lands and soils, were indicated. Specific attention was paid to the high potential of agriculture and rural areas (including forestry) in terms of the possible use of their resources in order to increase the sequestration of carbon in biomass and soil and reduce greenhouse gas emissions, as well as the use of agricultural and agro-food processing with wood biomass for renewable energy development, including the production of biogas and biofuels. Moreover, the principles of operation of a low-carbon economy and the main bearings of low-carbon development of rural areas were determined. Also the need was stressed to include agriculture and rural areas into the local planning of low-carbon economy and their recognition in low-carbon economy plans which are being prepared by local government units. The proposed solutions are the result of the research and analyses carried out, as an author, during the work on a Pilot programme of low-carbon development of Starogard county. It is the first of such documents dedicated to low-carbon economy, drawn on a county scale in Poland. 